\title{
Aplikasi Mikoriza dan Beberapa Varietas Kacang Tanah Dengan Pengolahan Tanah Konservasi terhadap Perubahan sifat Biologi Tanah
}

Application Micoriza and Baean Varieties by Conservation Tillage for Biological Soil Properties Improvement

Rini Susanti ${ }^{1}$, Astri Afriani ${ }^{2}$, Fitra Syawal Harahap ${ }^{3}$, Wizni Fadhillah ${ }^{1}$, Roswita Oesman $^{4}$, Hilwa Walida $^{3}$

\footnotetext{
${ }^{1}$ Progam Studi Agroteknologi Fakultas Pertanian Universitas Muhammadiyah Sumatera Utara, 20238

${ }^{2}$ Progam Studi Agroteknologi Fakultas Pertanian Universitas Samudra Langsa, Aceh 24354

${ }^{3}$ Program Studi Agroteknologi, Sekolah Tinggi Ilmu Pertanian Labuhanbatu Rantauprapat

${ }^{4}$ Progam Studi Agroteknologi Fakultas Pertanian Universitas Pembinaan Masyarakat Indonesia *Corresponding author : rinisusanti@umsu.ac.id
}

\begin{abstract}
Treating the soil too often can cause the soil to become more loose and open for a long time, thereby increasing the rate of evapotranspiration and reducing the holding capacity of the soil against water. reduce the holding power of the soil against water. Provision of biological fertilizers containing mycorrhiza is one solution to overcome these problems. bermikoriza is a fertilizer that is able to symbiosis with plant roots and serves to increase the availability of soil $\mathrm{pH}$ and $\mathrm{P}$ in the soil. In this regard, it is necessary to conduct research on the effectiveness of arbuscular mycorrhizal-based biofertilizer in increasing the total microbial availability of $P$ and increasing plant growth. The research was carried out in the Seed Seedling Plantations Office of Food Crops and Horticulture in Medan at N 98042'23,7 "and E 3030'28,3 "with a height of \pm $20 \mathrm{~m}$ above sea level starting from April 2008 until May 2018. The research design used is a Split Plot Design consisting of 3 factors, namely the Factor of Soil Processing as subplots consists of 3 levels: No Tillage (T0), Minimum Tillage (T1), Full Tillage (T2), Inoculation Factors Mycorrhiza as subplots consist of 2 levels: without mycorrhizal inoculation (MO), inoculation of mycorrhiza (M1). Factors of Varieties as subplots consist of 3 levels, namely: Local Varieties (V1). Elephant variety (V2) and deer variety (V3). The results of the study were to find out the soil treatment and the effect of mycorrhiza and the best combination of treatment systems, the addition of mycorrhiza and peanut varieties (Arachis hypogaea L.) for the best soil $p H$, organic C, available P, Organic Materials and Total Soil Microbes
\end{abstract}

Keywords: Soil Processing, Biological Properties of Soil, Mycorrhizae, Peanut Varieties

\begin{abstract}
ABSTRAK
Pengolahan tanah terlalu sering dapat menyebabkan tanah menjadi lebih gembur dan terbuka dalam waktu lama, sehingga meningkatkan laju evapotranspirasi dan mengurangi daya pegang tanah terhadap air. mengurangi daya pegang tanah terhadap air. Pemberian pupuk hayati yang mengandung mikoriza merupakan salah satu solusi untuk mengatasi permasalahan tersebut. bermikoriza merupakan pupuk yang mampu bersimbiosis dengan perakaran tanaman dan berfungsi untuk meningkatkan ketersedian PH Tanah dan P dalam tanah. Sehubungan dengan hal tersebut, maka diperlukan penelitian tentang uji efektifitas pupuk hayati berbasis mikoriza arbuskula dalam meningkatkan Total Mikroba ketesersedian P dan meningkatkan pertumbuhan tanaman Penelitian dilaksanakan dikebun Pembibitan Balai Benih Dinas Tanaman Pangan dan
\end{abstract}


Holtikultura Medan pada titik Koordinat N 98042'23,7” dan E 3 30'28,3" dengan ketinggian \pm $20 \mathrm{~m}$ diatas permukaan laut dimulai dari bulan April 2008 sampai dengan Mei 2018. Rancangan penelitian yang digunakan adalah Rancangan Petak Terpisah (Split Plot Design) yang terdiri dari 3 faktor yaitu Faktor Pengolahan Tanah sebagai anak petak yang terdiri dari 3 taraf : No Tillage (T0), Minimum Tillage (T1), Full Tillage (T2), Faktor inokulasi Mikoriza sebagai anak petak terdiri dari 2 taraf : tanpa inokulasi Mikoriza (M0), ipnokulasi Mikoriza (M1). Faktor Varietas sebagai anak-anak petak terdiri dari 3 taraf yaitu : Varietas Lokal (V1). Varietas gajah (V2) dan Varietas kancil (V3). Hasil Penelitian Untuk mengetahui pengolahan tanah dan pengaruh mikoriza serta kombinasi yang terbaik dari sistem pengolahan, penambahan mikoriza dan varietas kacang tanah (Arachis hypogaea L.) yang terbaik bagi peningkatan $\mathrm{pH}$ tanah, C-organik, P-tersedia, Bahan Organik Serta Total Mikroba Tanah

\section{Kata Kunci : Pengolahan Tanah, Sifat Biologi Tanah, Mikoriza, Varietas Kacang Tanah}

\section{PENDAHULUAN}

Salah satu tanaman semusim yang ditanam di lahan kering yang menjadi unggulan adalah kacang tanah karena mempunyai kadar minyak dan protein cukup tinggi. Kacang tanah memerlukan syarat tumbuh tanah yang subur, gembur, bertekstur ringan, dan berdrainase baik (Susilawati, 2010). Kacang tanah (Arachis hypogaea L.) merupakan tanaman legum terpenting setelah kedelai yang memiliki peran strategis dalam pangan nasional sebagai sumber protein dan minyak nabati. Sebagai bahan pangan dan makanan yang bergizi tinggi, kacang tanah mengandung lemak $40-50 \%$, protein $27 \%$, karbohidrat dan vitamin (Suprapto, 2004). Pengolahan tanah merupakan kegiatan utama dalam sistem pertanian, yang bertujuan untuk menjadikan lingkungan fisik tanah sesuai untuk pertumbuhan akar (Firnia, D. 2009).

$$
\text { Dengan pengolahan tanah }
$$

diharapkan kepadatan tanah dapat dikurangi sehingga aerasi tanah menjadi lebih baik (tata udara dan air) yang akan mendorong perkembangan perakaran, meningkatkan serapan hara dan air serta mengurangi senyawa-senyawa organik yang beracun (Soepardi, 1983). Pengolahan tanah yang baik menyebabkan akar tanaman dapat menembus tanah dengan mudah sehingga dapat merangsang berkembangnya mikroba di sekitar perakaran. Menurut Arsana (2007), umumnya kacang tanah menghendaki pengolahan tanah sempurna agar perkembangan akar dan pertumbuhan berlangsung dengan baik, sehingga ginofor mudah masuk ke dalam tanah membentuk polong dan mempermudah pemungutan hasil, tanpa banyak yang hilang atau tertinggal di dalam tanah dan pengolahan tanah dimaksudkan untuk menciptakan ruang tumbuh bagi tanaman, sehingga akan menopang pertumbuhan dan perkembangan di atasnya. Menurut Suwardjo and Dariah (1995), pengolahan tanah yang berlebihan juga mendorong meningkatnya proses oksidasi bahan organik sehingga menurunkan aktivitas mikroorganisme tanah seperti bakteri penambat nitrogen dan fosfor, menyebabkan menurunnya kandungan bahan organik tanah sehingga terjadi kemerosotan kesuburan tanah dan kemantapan agregat. Utomo, et al., (2010) melaporkan bahwa penerapan sistem olah tanah konservasi memberikan pengaruh signifikan karena dapat meningkatkan kelimpahan cacing tanah sampai $252 \%$, biomassa mikroba $70 \%$, dan kandungan $\mathrm{C}$ organik tanah sebesar $13,0 \%$, apabila dibandingkan dengan sistem olah tanah konvensional.

Tanah yang diolah berlebihan tanpa tindakan konservasi akan menjadi lebih cepat kering, lebih halus (powdery), berstruktur buruk dan berkadar bahan organik tanah rendah. Pengolahan tanah dapat diartikan sebagai kegiatan manipulasi mekanik terhadap tanah(Arsyad, 2000). Tujuannya adalah untuk mencampur dan menggemburkan tanah, mengontrol 
tanaman pengganggu, mencampur sisa tanaman dengan tanah dan menciptakan kondisi kegemburan tanah yang baik untuk pertumbuhan akar (Gill and Berg, 1967). Utomo (1995) mendefinisikan OTK sebagai suatu cara pengolahan tanah yang bertujuan untuk menyiapakan lahan agar tanaman dapat tumbuh dan berproduksi optimum, namum tetap memperhatikan aspek konservasi tanah dan air. Sistem OTK dicirikan oleh berkurangnya pembongkaran/pembalikan tanah, penggunaan sisa tanaman sebagai mulsa, dan kadang disertai penggunaan herbisida untuk menekan pertumbuhan gulma atau tanaman pengganggu lainnya. Persiapan lahan yang ditunjukkan dengan sistem tanpa olah tanah cenderung memiliki lebih banyak efek positif terhadap keanekaragaman beberapa biota tanah dibandingkan dengan pengolahan tanah konvensional (Makalewk, 2001). Meskipun pekerjaan mengolah tanah secara teratur dianggap penting, tetapi pengolahan tanah secara intensif dapat menyebabkan terjadinya degradasi tanah yang diikuti kerusakan struktur dan tekstur tanah, peningkatan terjadinya erosi tanah, dan penurunan kandungan bahan organik dalam tanah yang berpengaruh terhadap keberadaan biota tanah (Umar, 2004).

Mikoriza memperbaiki pertumbuhan dan hasil tanaman melalui perannya dalam memfasilitasi peningkatan ketersediaan $\mathrm{P}$ dalam tanah dan penyerapan unsur $\mathrm{P}$ dan 4 unsur hara lain oleh tanaman (Susilowati and Sukartono, 2007; Musfal, 2010). Musfal (2010) melaporkan inokulasi mikoriza $15 \mathrm{~g}$ per tanaman jagung di lahan kering terbukti dapat efisiensikan $50 \%$ penggunaan pupuk NPK dengan hasil pipilan jagung tidak berbeda secara nyata dengan pemberian $100 \%$ pupuk NPK. Di samping itu telah juga dilaporkan bahwa tanaman yang terinfeksi mikoriza menjadi lebih tahan terhadap cekaman kekeringan daripada tanaman tanpa mikoriza (Endang and Santosa, 2005). Namun demikian, kondisi lingkungan tanah yang berbeda, seperti tingkat kandungan bahan organik tanah, kelembaban tanah, tingkat ketersediaan $\mathrm{P}$ berpengaruh terhadap keefektifan mikoriza dalam menopang pertumbuhan dan hasil tanaman (Susilowati and Kartono, 2007). Pengolahan tanah dapat menciptakan kondisi yang mendukung perkecambahan benih dan mungkin diperlukan untuk memerangi gulma dan hama yang menyerang tanaman atau untuk membantu mengendalikan erosi. Pengolahan tanah di tingkat petani umumnya dilakukan dengan mengolah tanah secara intensif sampai gembur pada seluruh permukaan tanah setiap akan menanam dan biasanya dilakukan 2-3 kali pembajakan. Cara pengolahan tanah tersebut disebut pengolahan konvensional (conventional tillage).

Cara pengolahan tanah seperti demikian dapat membantu pertumbuhan dan perkembangan tanaman secara optimal, tetapi dampak positif tersebut hanya sementara, karena untuk jangka panjang akan berdampak negatif terhadap produktivitas lahan dan tanaman. Menurut Utomo (1999) dan Suwardjo et al. (1989), kerusakan lingkungan tanah di daerah tropika basah termasuk Indonesia, selain disebabkan oleh ekosistem yang kondusif terhadap degradasi tanah, juga dipacu oleh pengolahan tanah yang intensif. Penanaman sayuran secara terus menerus tanpa menjaga kelestarian lingkungan tumbuh, terutama tanah, dapat menyebabkan rusaknya fisik tanah dan biota yang terkandung dalam tanah serta hilangnya unsur-unsur hara dalam tanah. Pemberian pupuk hayati yang mengandung mikoriza merupakan salah satu solusi untuk mengatasi permasalahan tersebut. Pupuk Hayati bermikoriza merupakan pupuk yang mamp bersimbiosis dengan perakaran tanaman dan berfungsi untuk meningkatkan ketersedian $\mathrm{P}$ dalam tanah. Menurut Rusdi (2011) bahwa pemberian mikoriza dengan dosis tinggi tidak berbanding lurus dengan pertumbuhan tanaman. Menurut hasil penelitian Utomo (1990) dan Niswati (1997) dalam Utomo (1999), jumlah bakteri, mikoriza, meso fauna, dan cacing tanah meningkat pada cara 
pengolahan tanah konservasi (tanpa olah tanah dan olah tanah minimum) pada musim ke-21. Utomo, et al., (2010) melaporkan bahwa penerapan sistem olah tanah konservasi memberikan pengaruh signifikan karena dapat meningkatkan kelimpahan cacing tanah sampai $252 \%$, biomassa mikroba $70 \%$, dan kandungan $\mathrm{C}$ organik tanah sebesar 13,0\%, apabila dibandingkan denga sistem olah tanah konvensional. Indria, A. T. (2005). Selain itu juga pupuk organik ini apabila diberikan pada tanah sebagai media tumbuh yang akan mempengaruhi sifat kimia, fisika maupun biologi tanah dan dapat digunakan sebagai bahan untuk memperkaya bahan organik tanah (Murbandono, 1988). Sifat biologi tanah dicirikan dengan rendahnya jumlah mikrobia tanah pendaur hara seperti bakteri pelarut fosfat yang populasinya hanya sekitar 104cfu/gam tanah, sementara tanah subur mencapai $10^{7} \mathrm{cfu} / \mathrm{gam}$ tanah (Arifin et al., 2017). Penelitian bertujuan Untuk mengetahui pengaruh Mikoriza dan system olah tanah terbaik dalam memperbaiki $\mathrm{pH}$ tanah, C-organik, P-tersedia, Bahan Organik Serta Total Mikroba Tanah

\section{BAHAN DAN METODE}

Penelitian ini dilaksanakan di kebun pembibitan balai benih pembantu Dinas Tanaman pangan dan Holtikultura Jl keramata indah selambo ujung Binjai Amplas Medan. $\pm 20 \mathrm{~m} \mathrm{dpl}$ pada titik koordinat N 98042'23,7' dan E $3^{0} 30$ '28,3'. Analisis Laboratorium dilaksanakan di Fisika Tanah dan Konservasi Tanah \& Air serta Laboratorium Riset dan Teknologi Fakultas Pertanian Penelitian ini di mulai bulan April 2018 sampai dengan selesai.

Bahan yang digunakan antara lain : Kacang tanah varietas lokal, varietas singa dan varietas jerapah, Mycofer. Bibit jagung.Sedangkan pupuk yang digunakan adalah Urea, TSP, dan KCl. Pencegahan hama penyakit digunakan Decis 2,5 EC dan Dithane M-45. Jenis Tanah Inseptisol
Alat yang digunakan anatar lain : mesin pemotong rumput, cangkul, garu, babat, tugal, ember, knapsack sprayer, gembor, gunting, pisau, meteran, timbangan, Leaf Area Meter, GPS, label, Spidol Permanen, ring sampel, permeabilimeter, dan alat-alat lainnya.

Rancangan penelitian yang digunakan adalah Rancangan Petak Terpisah (Split Plot Design) yang terdiri dari 3 faktor yaitu; Faktor I : Pengolahan Tanah, terdiri dari 3 taraf; T0 $=$ Tanpa olah tanah ( No-Tillage) $\mathrm{T} 1=$ Pengolahan tanah terbatas ( Minimum Tillage) $\mathrm{T} 2=$ Pengolahan tanah sempurna (Full Tillage)

Faktor II : Pemberian Mikoriza, terdiri dari 2 taraf; $\mathrm{M} 0=$ Tanpa Inokulasi M1 = Penambahan Inokulasi Mikoriza Faktor III : Varietas, terdiri dari 3 taraf ; VI $=$ Varietas Lokal,V2 = Varietas Gajah, V3 = Varietas Kancil

Dengan demikian diperoleh 18 kombinasi perlakuan dan setiap kombinasi diulang sebanyak 3 kali, sehingga jumlah petak perlakuan adalah 54 petakPerlakuan yang menunjukkan pengaruh yang nyata terhadap peubah yang diamati dilanjutkan dengan Uji Regressi.

\section{Persiapan Lahan}

a. Tanpa Olah Tanah ( No Tillage )

Lahan dibuat petakan percobaan sesuai ukuran kemudian lahan dibabat/dipangkas untuk mengendalikan gulma dan tumbuhan lainnya, sisa tanaman dan gulma sebelumnya dikembalikan/tetap berada di dalam lahan pembubidayaan. Kemudian dilakukan penanaman benih dengan tugal kedalaman $3-5 \mathrm{~cm}$.

b. Pengolahan Tanah Terbatas (Minimum Tillage )

Lahan dari petakan percobaan sesuai ukuran yang telah ditentukan dikikis dengan cangkul atau babat sampai rata dengan tanah. Sisa tanmaan dan gulma sebelumnya masih tetap dilahan. Langkah selanjutnya pengolahan tanah dilakukan pada baris tanaman dengan pencangkulan yang 
bertujuan untuk menempatkan benih kacang tanah.

c. Pengolahan Tanah Sempurna (Full Tillage )

Lahan areal penelitian dibersihkan dari gulma dan tanaman lain yang tumbuh diatasnya, lalu lahan dilakukan pencangkulan pertama. Satu minggu kemudian dilakukan pencangkulan yang kedua diteruskan dengan penghalusan, perataan dengan garu. Petak percobaan dibagi dalam 3 ulangan dengan ukuran per ulangan 6,0 x 16,4 m, jarak antar ulangan $100 \mathrm{~cm}$. Seterusnya setiap ulangan ini dibagi atas 18 petak dengan ukuran petak 210 x 160 $\mathrm{cm}$ : jarak antar petak $60 \mathrm{~cm}$.

\section{Penanaman}

Benih yang akan ditanam terlebih dahulu diseleksi, kemudian benih direndam dengan fungisida Dithane M-45 dengan konsentrasi $2 \mathrm{cc} /$ liter selama 10 menit. Benih ditanam dengan kedalaman 3-5 cm sebanyak 2 benih/lubang dengan jarak tanam 20x30 $\mathrm{cm}$.

\section{Aplikasi MVA}

Mikoriza diaplikasi pada benih yang akan ditanam dengan cara memcampurkan benih dengan Mycofer Mikoriza sebanyak 5 gram perlubang tanam atau pertanaman.

\section{HASIL DAN PEMBAHASAN}

Hasil pengujian pemebrian Mikoriza pada varietas kacang tanah dengan pengolahan tanah konservasi terhadap sifat kimia dan biologi tanah. Data dan Hasil analisis sidik ragam terhadap sifat Dari $\mathrm{pH}$ tanah, C-organik, P-tersedia, Bahan Organik Serta Total Mikroba Tanah dapat diketahui bahwa pengolahan tanah konservasi, inokulasi mikoriza, jenis varietas serta interaksi perlakuan berpengaruh tidak nyata terhadap $\mathrm{pH}$ Tanah, C-organik, P-tersedia sedangkan perlakuan inokualsi mikoriza dan jenis varietas kacang tanah serta interaksi tidak berpengaruh nyata terhadap semua parameter $\mathrm{pH}$ tanah, C-organik, P-tersedia, Bahan Organik Serta Total Mikroba Tanah disajikan pada Tabel 1.

Tabel 1. Rataan $\mathrm{pH}$ tanah, C-organik, P-tersedia, Bahan Organik Serta Total Mikroba Tanah akibat Perlakuan pemebrian Mikoriza pada varietas kacang tanah (Arachis hypogaea L.) dengan pengolahan tanah konservasi terhadap sifat biologi tanah

\begin{tabular}{lccccc}
\hline \multicolumn{1}{c}{ PERLAKUAN } & pH Tanah & $\begin{array}{c}\text { C-Organik } \\
(\%)\end{array}$ & $\begin{array}{c}\text { Bahan } \\
\text { Organik } \\
(\%)\end{array}$ & $\begin{array}{c}\text { P-Tersedia } \\
(\mathrm{ppm})\end{array}$ & $\begin{array}{c}\text { Total } \\
\text { Mikroba } \\
(\mathrm{CFU} / \mathrm{ml})\end{array}$ \\
\hline $\begin{array}{l}\text { Pengolahan Tanah } \\
\text { T0 (No-Tillage) }\end{array}$ & 5.49 & 1.28 & 2.20 & 4.73 & $3.2 \times 10^{4}$ \\
T1 (Minimum Tillage) & 5.52 & 1.25 & 2.15 & 4.83 & $4.2 \times 10^{4}$ \\
T2 (Full Tillage) & 5.53 & 1.23 & 2.12 & 5.40 & $2.2 \times 10^{4}$ \\
& & & & & \\
Mikoriza & 5.51 & 1.98 & 3.41 & 4.62 & $4.5 \times 10^{6}$ \\
M0 (Tanpa Inokulasi & 5.54 & 2.09 & 3.60 & 5.05 & $6.5 \times 10^{6}$ \\
Mikoriza) & & & & & \\
M1(Inokulasi Mikoriza) & & & & & \\
& 5.54 & 1.37 & 2.36 & 4.53 & $2.2 \times 10^{4}$ \\
Varietas & 5.48 & 1.29 & 2.21 & 4.31 & $4.2 \times 10^{4}$ \\
V1(Varietas Lokal) & 5.52 & 1.18 & 2.03 & 5.37 & $3.2 \times 10^{4}$ \\
V2(Varietas Gajah) & & & &
\end{tabular}


Keterangan : Rataan yang diikuti oleh huruf yang sama pada setiap kolom yang sama untuk setiap perlakuaan yang sama tidak berbeda nyata Pada P 0,05

Perlakuan pengolahan tanah maksimum tidak berbeda dengan perlakuan pengolahan tanah minimum namun berbeda dengan perlakuan tanpa olah tanah. Hal ini disebabkan oleh adanya perbedaan sifat fisik tanah dari masing-masing perlakuan. Selanjutnya Jumin (2012) menyatakan bahwa sifat fisis, kimia dan biologi tanah berubah dengan adanya pengolahan tanah yang tepat dan sempurna. Hal ini disebabkan terpecahnya agregat tanah menjadi lebih halus. Akibatnya udara dan air lebih leluasa masuk ke dalam tanah, yang menyebabkan terjadi perubahan struktur dan komposisi kimia tanah. Perubahan kimia tanah juga akan mengubah sifat biologis tanah, karena kedua faktor itu saling berpengaruh. Persiapan lahan yang ditunjukkan dengan sistem tanpa olah tanah cenderung memiliki lebih banyak efek positif terhadap keanekaragaman beberapa biota tanah dibandingkan dengan pengolahan tanah konvensional (Makalewk, 2001).

Pemberian bahan organik dapat memperbaiki sifat fisik dan kimia tanah, tetapi mutu bahan organik dipengaruhi oleh tingkat penguraiannya. Semakin cepat tingkat penguraiannya, bahan organik semakin mudah tersedia. Bahan organik sangat penting karena berasal dari tanaman yang tertinggal, berisi semua unsur hara yang dibutuhkan untuk pertumbuhan tanaman menurut Menurut Wahyunie et al. (2012), penerapan olah tanah intensif memiliki kadar air lebih rendah dibandingkan dengan tanpa olah tanah karena proses membolakbalik/membongkar tanah dapat menyebabkan terjadinya disperi agregat serta penyumbatan pori yang dapat menurunkan sebaran pori makro dan meningkatkan jumlah pori mikro. Bahan organik mempengaruhi struktur tanah dan menjaga kondisi fisik yang diinginkan (Stevensen, 1982).

Tanah mempunyai kualitas yang baik jika dapat mendukung kelangsungan hidup organisme di dalam dan di atasnya, Hal ini tidak terlepas dari fungsi tanah sebagai tempat aktivitas biologi, mengatur dan membagi air serta berfungsi sebagai penyangga (buffer capacity). Tanah sebagai tempat aktivitas biologi terdapat beberapa fungsi indikator yang mendukung aktivitas biologi yaitu media perakaran, kelengasan dan nutrisi atau keharaan. Penentukan fungsi indikator tanah dengan menggunakan beberapa parameter tanah kandungan Ptersedia berstatus rendah, akan tetapi kandungan unsur $\mathrm{K}$ berharkat tinggi dan tingkat kemasamantanahnya ber-pHnetral (Kusumo et al, 2011).

Sifat biologi tanah dicirikan dengan rendahnya jumlah mikrobia tanah pendaur hara seperti bakteri pelarut fosfat yang populasinya hanya sekitar $10^{4} \mathrm{cfu} /$ gam tanah, sementara tanah subur mencapai $10^{7}$ cfu/gam tanah, Di samping itu telah juga dilaporkan bahwa tanaman yang terinfeksi mikoriza menjadi lebih tahan terhadap cekaman kekeringan daripada tanaman tanpa mikoriza (Endang dan Santosa, 2005). Namun demikian, kondisi lingkungan tanah yang berbeda, seperti tingkat kandungan bahan organik tanah, kelembaban tanah, tingkat ketersediaan $\mathrm{P}$ berpengaruh terhadap keefektifan mikoriza dalam menopang pertumbuhan dan hasil tanaman(Susilowati dan Kartono, 2007).

Secara umum, status hara dalam tanah dapat memengaruhi produksi tanaman disebabkan adanya serapan hara oleh akar tanaman (Chang et al. 2010). Penyerapan hara $\mathrm{P}$ dari tanah oleh akar tanaman dipengaruhi oleh proses dekomposisi bahan organik tanah terkait dengan luasan permukaan pertukaran kation dan anion yang dipengaruhi oleh $\mathrm{pH}$ tanah (Moreira et al. 2011). Mikoriza memperbaiki pertumbuhan dan hasil tanaman melalui perannya dalam memfasilitasi peningkatan ketersediaan $\mathrm{P}$ dalam tanah dan penyerapan unsur $\mathrm{P}$ dan unsur hara lain oleh tanaman (Susilowati dan Sukartono, 2007; Musfal, 
2010) Di samping itu telah juga dilaporkan bahwa tanaman yang terinfeksi mikoriza menjadi lebih tahan terhadap cekaman kekeringan daripada tanaman tanpa mikoriza (Endang and Santosa, 2005). Namun demikian, kondisi lingkungan tanah yang berbeda, seperti tingkat kandungan bahan organik tanah, kelembaban tanah, tingkat ketersediaan $\mathrm{P}$ berpengaruh terhadap keefektifan mikoriza dalam menopang pertumbuhan dan hasil tanaman (Susilowati and Kartono, 2007).

Manfaat FMA juga dilaporkan oleh Bolan (1991) FMA dapat melepaskan P yang terfiksasi oleh $\mathrm{Al}$ dan $\mathrm{Fe}$ pada lahan masam dengan menghasilkan enzim fosfatase sehingga $\mathrm{P}$ akan tersedia bagi tanaman Menurut Prihastuti (2007), MVA dapat hidup dengan baik pada $\mathrm{pH}$ tanah masam. Keberadaan MVA ditentukan oleh musim. Kelimpahan MVA terjadi pada musim semi dan awal musim panas, kadang tidak ada atau hanya dalam bentuk spora pada saat dormansi akar atau saat tidak ada tanaman sama sekali Hal ini diduga karena karbon (C) merupakan penyusun utama kompos dengan demikian semakin tinggi dosis kompos yang digunakan maka peningkatan C-organik juga semakin tinggi. Refliaty et al., (2011) berpendapat bahwa terjadinya peningkatan C-organik seiring dengan penambahan bahan organik. Dimana hasil dekomposisi bahan organik (karbon) sebagian akan masuk ke dalam jaringan mikrobia tanah untuk membentuk jaringan dan menyusun sel, selanjutnya menjadi bagian yang labil dan akhirnya mentransformasikan ke dalam bentuk humus yang stabil. Anas (2000) menyatakan bahwa $\mathrm{C}$ yang terkandung dalam bahan organik mencapai $48 \%-58 \%$ dari berat total bahan organik itu sendiri.

\section{SIMPULAN DAN SARAN}

Inokulasi mikoriza berpengaruh tidak nyata terhadap sifat kimia dan biologi tanah pH tanah, C-organik, P-tersedia, Bahan Organik Serta Total Mikroba Tanah
Jenis varietas berpengaruh tidak nyata terhadap semua parameter $\mathrm{pH}$ tanah, C-organik, P-tersedia, Bahan Organik Serta Total Mikroba Tanah

Interaksi pengolahan tanah dan inokulasi mikoriza berpengaruh tidak nyata terhadap pH tanah, C-organik, P-tersedia, Bahan Organik Serta Total Mikroba Tanah

\section{Saran}

Pertanaman kacang tanah dapat dilakukan dengan pengolahan tanah minimum tillage (T1) dan tanpa olah tanah (T0) sehingga penggunaan inokulasi mikoriza kurang sesuai untuk pertanaman kacang

\section{DAFTAR PUSTAKA}

Anas. I., 2000. Potensi Kompos Kota Untuk Pertanian Di Indonesia. Seminar Lokakarya pengelolaan Sampah Organik Untuk Mendukung Program Ketahanan Pangan dan Kelestarian Lahan Pertanian. Faperta Unibraw. Malang. h:1-9

Arsyad S. 2000. Pengawetan Tanah dan Air. Bogor: Departemen Ilmu-llmu Tanah. Fakultas Pertanian. Institut Pertanian Bogor.

Arifin, Z., Susilowati, L. E., \& Kusuma, B. H. (2017). PERUBAHAN INDEKS KUALITAS TANAH DI LAHAN KERING AKIBAT MASUKAN PUPUK ANORGANIKORGANIK. AGROTEKSOS, Jurnal Ilmiah Ilmu Pertanian, 26(2), 1-17.

Arsana. IGK.D. 2007. Peningkatan Produksi Kacang-kacangan dan Umbiumbian Mendukung Kemandiarian Pangan. Pengkajian Shuttle Breeding Kacang Tanah di Lahan Kering Beriklim Kering Dataran Rendah Gerokgak-Buleleng. Balai Pengkajian Teknologi Pertanian, Bali. Hal 200 -2004. 
Bolan, N.S. 1991. A Critical Review On The Role Of Mycorrhizal Fungi In The Uptake Of Phosphorus By Plants. Plant And Soil 134: 189207p

Chang KH, Wu RY, Chuang KC, Hsieh TF, Chung RS. 2010. Effects of chemical and organic fertilizers on the growth, flower quality and nutrient uptake of Anthurium andreanum cultivated for cut flower production. Scientia Horticulturae. 125(3): 434-441.

Endang, P. dan Santosa. 2005. Efisiensi pemupukan fosfat, ketahanan terhadap kekeringan dan pertumbuhan kacang tanah (Arachishypogae L.) dengan inokulasi jamur mikoriza vesikular-arbuskular pada tanah berkapur. Program Studi Biologi Sekolah Pascasarjana Universitas Gadjah Mada, Yogyakarta. $15 \mathrm{hlm}$.

Firnia, D. (2009). SIFAT KIMIA ULTISOLS BANTEN AKIBAT PENGOLAHAN TANAH DAN PEMBERIAN PUPUK KOMPOS. Jurnal Agroekoteknologi, 1(1).

Gill WR, Vanden Berg GE. 1967. Soil Dynamics in Tillage a USDA Agric. Washington DC: Handb. N. 316. U.S. Government Printing.

Indria, A. T. (2005). Pengaruh sistem pengolahan tanah dan pemberian macam bahan organik terhadap pertumbuhan dan hasil kacang tanah (Arachis hypogaea L.) (Doctoral dissertation, Universitas Sebelas Maret).

Jumin, H. B. 2002. Agronomi. PT. Raja Grafindo Persada. Jakarta.

Utomo, M. 1999. Teknologi Olah Tanah Konservasi Menuju Pertanian Berkelanjutan. Prosiding
Seminar Nasional Pertanian

Organik. Palembang, 30

Oktober 1999. Fakultas

Pertanian, Universitas IBA

Palembang.16 Hlm. I

Endang, P. dan Santosa. 2005. Efisiensi pemupukan fosfat, ketahanan terhadap kekeringan dan pertumbuhan kacang tanah (Arachishypogae L.) dengan inokulasi jamur mikoriza vesikular-arbuskular pada tanah berkapur. Program Studi Biologi Sekolah Pascasarjana Universitas Gadjah Mada, Yogyakarta. $15 \mathrm{hlm}$.

Makalew, A. D. N. 2001. Keanekaragaman biota tanah pada agroekosistem tanpa olah tanah (TOT). Science Phylosophy Paper. Graduate Program, Bogor Agricultural University.

Matos-Moreira M, Lopez-Mosquera ME, Cunha M, Oses MJS, Rodríguez T, Carra EV. 2011. Effects of Organic Fertilizers on Soil Physicochemistry and on the Yield and Botanical Composition of Forage over 3 Years. Journal of the Air \& Waste Management Association. 61(7): 778-785.

Musfal. 2010. Potensi Cendawan Mikoriza Arbuskula Untuk Meningkatkan Hasil Tanaman Jagung. Jurnal Litbang Pertanian, 29(4), 154158.

Murbondono, HS. 1988. Membuat Kompos. Rineka Cipta, Jakarta.

Prihastuti. 2007. Peluang dan tantangan aplikasi pupuk hayati pada tanaman kacang-kacangan. Berk. Penel. Hayati: 12:99-106.

Refliaty, Tampubolon dan Hendriansyah. 2011.Pengaruh Pemberian Kompos Biogas Sapi Terhadap Perbaikan Beberapa Sifat Fisik Ultisol Dan Hasil Kedelai. 
Susilowati, L.,E. 2011. Perbaikan sifat Fisik dan Kimia Tanah Berbahan Indul Batu Apung Melalui Masukan Perimbangan Kombinasi Pupuk Anorganik, Organik dan Hayati. Prosiding. Seminar dan Kongres Nasional HITI. UNS-solo., 6-8 Desember 2011

Susilawati, P.N. 2010. Budidaya Kacang Tanah pada Lahan kering. BPTP Banten. Badan Litbang Deptan.

Suprapto, 2004. Bertanam kacang tanah. Penebar Swadaya. Jakarta.

Suwardjo,M., H. Suhardjo, dan S.H. Talauhu. $\quad 1989 . \quad$ Pengaruh Panjang Lereng dan Cara Pengelolaan Lahan terhadap Pertumbuhan dan Hasil Kacang Tanah. Pros. Penel. Tanah. 6:375-382.

Suwardjo, H. dan A. Dariah. 1995. Teknik Olah Tanah Konservasi untuk Menunjang Pengembangan Lahan Kering yang Berkelanjutan. Prosiding Seminar Nasional V. BDPOTK. Bandar Lampung, 8-9 Mei 1995. p. 8-13.

Susilowati dan Kartono, 2007. Respon tanaman bawang merah (Allium ascalonicum) yang diinokulasi MVA pada ragam cara pemberian bahan organik dan jeda pengairan di Lahan Kering Pulau Lombok. Prosiding Kongres Nasional HITI 5-7 Desember 2007, YOGYAKARTA.

Stevensen, E.J. 1982. Humus Chemistry Genesis, Compotition, and Reaction. John Willey and Sons. New York. 67 hal.

Soepardi, G. 1983. Sifat dan Ciri Tanah. Jurusan Tanah Fakultas Pertanian IPB, Bogor.

Utomo M. 1995. Kekerasan tanah dan serapan hara tanaman jagung pada olah tanah konservasi jangka panjang. J. Tanah Trop. $1: 1-7$.

Utomo, M., A. Niswati, Deriyati, M.R. Wati, E.F. Raguan and S. Syarif. 2010. Earthworm and Soil Carbon Sequestration after Twenty One Years of Continuous No-tillage Corn-Legume Rotation in Indonesia. JIFS. $7: 51-58$.

Utomo, M., A. Niswati, Deriyati, M.R. Wati, E.F. Raguan and S. Syarif. 2010. Earthworm and Soil Carbon Sequestration after Twenty One Years of Continuous No-tillage Corn-Legume Rotation in Indonesia. JIFS. 7 : $51-58$.

Wahyunie E.D., Baskoro, D.P.T dan Sofyan, M. 2012. Kemampuan retensi air dan ketahanan penetrasi tanah pada sistem olah tanah intensif dan olah tanah konservasi. Jurnal Tanah Lingkungan 14 (2), 73-78. 